guard its interests very jealously in the current debate on university funding, and nowhere more energetically than in medical education.

Dean and Professor of Medicine,

St Mary's Hospital Medical School,

London W2 1 PG

1 Association of Professors of Obstetrics and Gynaecology. The effects of the present financial crisis on academic departments of obstetrics and gynaecology. Br Med f 1983;287:771-4.

${ }^{2}$ Kessel N. Academic medicine in peril. Lancet 1983;ii:899-901.

${ }^{3}$ Royal Commission on University Education in London. Final report. London: HMSO, 1913:para 301. (Cmd 6717.)

${ }^{4}$ Peart WS. Rebirth of the professor of medicine. Lancet 1983; : $: 810-2$.

s Mitchell JRA. The unkindest cut of all: a view of the UGC cuts from Britain's first 20th-century medical school. Lancet 1982;ii:540-5.

${ }^{6}$ Dainton F. Reflections on the universities and the National Health Service. London: Nuffield Provincial Hospitals Trust, 1983:152.

\section{Are antithyroid drugs immunosuppressive?}

Graves' disease is an autoimmune disorder in which hyperthyroidism results from thyroid stimulating antibodies binding to the thyroid cell membrane and stimulating thyroid hormone biosynthesis. Two papers in this issue present new data on the mechanism of action of antithyroid drugs in Graves' disease (pp 518 and 526). The authors claim that as well as blocking the synthesis of thyroid hormone these drugs suppress production of the pathogenic antibodies, and they discuss the mechanisms which may bring about this reduction. The view that antithyroid drugs are immunosuppressive is controversial, and the evidence deserves careful review.

Antithyroid drugs inhibit iodine organification but have no direct effect on the concentration of inorganic iodide by the thyroid. The drugs include the thiouracil drugs and carbimazole, which is rapidly converted to its active metabolite methimazole, and depend for their activity on a thiocarbamide group $(\mathrm{S}=\mathrm{C}-\mathrm{N})$. They bind to thyroid peroxidase competitively with iodide, so inhibiting the oxidation of iodide as well as other reactions catalysed by the enzyme, including the iodination of tyrosyl residues in thyroglobulin and the coupling to form iodothyronines. ${ }^{1-3}$

Doctors have long recognised that in about a third of patients with Graves' hyperthyroidism the disease remits spontaneously. ${ }^{45}$ The first fundamental question, therefore, is whether carbimazole influences the remission rate. If it merely suppresses thyroid hormone synthesis until such time as remission occurs spontaneously then the remission rate will not have changed much since antithyroid drugs were introduced in about 1944. Furthermore, if antithyroid drugs do not affect the underlying disease then the dose and the duration of treatment would be unlikely to influence remission rates. Many series of patients treated with antithyroid drugs have been reported with remission rates varying from $30 \%$ to $75 \% \%^{6.11}$ Obviously the figures depend on how remission is defined; their interpretation must take into account the fluctuating course of Graves' disease ${ }^{12}$ and also other factors such as iodine intake that influence the outcome. ${ }^{1314}$ The remission rate is probably lower in those treated with propranolol alone than in those treated with antithyroid drugs, despite the fact that milder cases are selected for propranolol treatment. ${ }^{15-17}$ The duration of antithyroid treatment varies from one to two years in most series. When treatment is prolonged beyond this the remission rate improves, ${ }^{1018}$ whereas in a study of short term treatment (mean 4.8 months) the remission rate was $29 \% \cdot{ }^{19} \mathrm{~A}$ study of relapse rates also found an association with duration of treatment, varying from $49 \%$ to $91 \%$ after five years. ${ }^{20}$ The remission rate may also be improved if the dose is increased, thus in a comparison of $60 \mathrm{mg}$ methimazole daily with $14 \mathrm{mg}$ daily for $13-15$ months the remission rates were $75 \%$ and $42 \%$ respectively. ${ }^{21}$ Further evidence comes from studies of technetium uptake during treatment: technetium uptake reflects iodine trapping, and antithyroid drugs have no direct effect on trapping, yet a progressive decline in technetium uptake was seen during treatment with carbimazole, indicating an effect at a stage before thyroid hormone biosynthesis. ${ }^{22}{ }^{23}$ Although these data do not prove conclusively that antithyroid drugs influence the course of the disease, they are highly suggestive.

Next we must consider effects on thyroid lymphocytes, serum antibody titres, and $\mathrm{T}$ cell activity in patients receiving these drugs. Michie et al first suggested that the drugs might act on lymphoid tissue and autoantibody production when they observed a decrease in the size of the thymus in patients treated preoperatively with carbimazole. ${ }^{24}$ Later they showed that the thymus involution and decreased lymphocytic infiltration of the thyroid that were seen during treatment with carbimazole were not seen in patients treated with propranolol. ${ }^{25}$ This led them to postulate that the drugs had an immunosuppressive effect, and they also suggested that investigating the pharmacological effects of carbimazole might lead to a better understanding of the pathogenesis of the disease. This we are now beginning to see. Since these observations evidence has mounted that antithyroid drugs block autoantibody production. Falling titres of long acting thyroid stimulator, ${ }^{26}$ thyrotrophin binding inhibiting immunoglobulin, ${ }^{27-29}$ thyroid stimulating antibody, ${ }^{30}$ and microsomal antibody ${ }^{29}$ have been reported during treatment. Also in an animal model of experimental autoimmune thyroiditis the severity of the thyroiditis in euthyroid rats was decreased by pretreatment with methimazole, and this was accompanied by a fall in thyroglobulin antibody titre..$^{31} \mathrm{~T}$ cell activity is also influenced by antithyroid drugs, as was first shown using tritiated thymidine uptake by peripheral blood lymphocytes. ${ }^{32}$ More recently several groups using OKT8 mouse monoclonal antibody to distinguish suppressor/cytotoxic $\mathrm{T}$ cells have shown a decrease in the number of $T$ suppressor cells in untreated patients and also in their activity. ${ }^{33}$ This finding has been extended by Ludgate et al (p 526), who have found in addition an increase in activated $T$ cells and a return of these $\mathrm{T}$ cell abnormalities to normal during six months of treatment with carbimazole.

These effects on lymphocytes could be secondary to the decreased thyroid hormone synthesis rather than a direct effect. In vitro studies are therefore important. McGregor et al cultured in vitro peripheral blood lymphocytes from patients with Hashimoto's disease and found that IgG synthesis and thyroid antibody production were inhibited in the presence of methimazole $10 \mu \mathrm{mol} / \mathrm{l}$ but not propranolol. ${ }^{29}$ These results were confirmed in a second study, but a higher concentration $(100 \mu \mathrm{mol} / \mathrm{l})$ of methimazole was needed. ${ }^{34}$ Thyroid hormones did not influence these results. Most of the thyroid antibodies are probably produced by lymphocytes within the thyroid, so the drug concentration achieved in the thyroid is more important than the blood concentration. Only recently has it been possible to measure the thyroid concentration in patients, and the results suggest that the thyroidal concentrations of methimazole may be less than those reported to be immunosuppressive. There was also no correlation 
between thyroid and serum concentrations, and the higher doses did not lead to greater thyroid concentration. ${ }^{35}$ The group who did the work postulated that the apparent immunosuppressive effect of methimazole may result from changes in the expression of antigenic sites secondary to lowered hormone concentrations. Further studies will be needed to establish this point, and it may be a mistake to extrapolate doses from in vitro cell cultures to the patient. The specificity of the effect may relate to the proximity of thyroid antibody production to the site of accumulation of methimazole within the thyroid, since gastric parietal cell antibody titres were unchanged during treatment with carbimazole. ${ }^{36}$

The results of all these studies have stimulated more work to establish a clear immunosuppressive effect of antithyroid drugs and to elucidate the mechanism. Methimazole is taken up by cells containing peroxidase; macrophages and monocytes have a peroxidase system, whereas lymphocytes do not. Experiments were therefore designed to see if methimazole acted on these cells. The results indicated that the suppressed production of thyroglobulin antibodies by lymphocytes from patients with Hashimoto's disease was not a direct effect on the lymphocytes but rather reflected an action on the handling of antigen by antigen presenting cells. ${ }^{37}$ Thus, although changes have been shown in tissue lymphocytes, in antibody production, and in $\mathrm{T}$ cell ratios during antithyroid drug treatment, the primary site of action may be on accessory cells. The data on page 519 show that methimazole inhibits oxygen radical generation by monocytes, probably through peroxidase inhibition, since studies with guaiacol oxidation indicate that that these compounds are general inhibitors of peroxidases; they also block the generation of free iodine radicals in thyroid cells. Alternatively, methimazole may be a scavenger of free radicals, which is suggested by its close structural similarity to thiourea, a known scavenger. A further question of interest is how the free radicals might influence autoimmune responses. Little is known of their effects on immune responsive cells, but they are important for the bactericidal action of phagocytes and in certain circumstances may be potent cytolytic agents. One might also speculate on the effect of iodine in this system: the thyroidal concentration of iodide influences both the accumulation of methimazole ${ }^{3}$ and its interaction with peroxidases in thyroid cells. ${ }^{2}$ Also enzymes derived from macrophages metabolise hydrogen peroxide in the presence of iodide to form additional potent oxidants. ${ }^{38}$ Perhaps, therefore, iodide may modulate the inhibition of monocytes by methimazole, which might relate to the known influence of iodine intake on the development of autoimmune thyroid disease and on the response to drug treatment.

These questions should be pursued. The answers will establish whether antithyroid drugs are truly immunosuppressive and will also shed light on the mechanisms of the autoimmune response. If we accept the arguments for an immunosuppressive effect then the objective in treating Graves' disease should be not only to control the hyperthyroidism but also to induce remission. This aim may lead to revised recommendations for using the drug-for example, treatment with continuing moderately high dosage for more than a year might be recommended. The triiodothyronine suppression test ${ }^{18}$ and TBII assay in conjunction with DR antigen typing may be usseful indicators of when treatment may be stopped, 3940 although we still cannot predict accurately which patients will achieve lasting remission.

P KeNDALL-TAYLOR

Consultant Physician and Reader in Endocrinology,

Royal Victoria Infirmary,

Newcastle upon Tyne NE1 4LP
' Taurog A. Thyroid peroxidase and thyroxine biosynthesis. Recent Prog Horm Res $1970 ; 26: 189-247$.

2 Taurog A. The mechanism of action of the thioureylene antithyroid drugs. Endocrinology 1976;98:1031-46.

${ }^{3}$ Marchant B, Lees JF, Alexander WD. Antithyroid drugs. Pharmacol Ther [B] 1978;3:305-48.

'White WH. The outlook of sufferers from exophthalmic goitre. $Q \mathcal{f}$ Med 1910;4:89-108.

${ }^{5}$ Wilson GM. The treatment of thyrotoxicosis. In: Royal College of Physicians of Edinburgh. Symposium on thyroid disease and calcium metabolism. Edinburgh: Royal College of Physicians, 1976:51-75.

${ }^{6}$ Hershman JM, Givens JR, Cassidy CE, Astwood EB. Long-term outcome of hyperthyroidism treated with antithyroid drugs. $\mathcal{F}$ Clin Endocrinol Metab 1966;26:803-7.

' Lowry RC, Lowe D, Hadden DR, Montgomery DAD, Weaver JA. Thyroid suppressibility: follow-up for two years after antithyroid treatment. Br Med F 1971 ; ii :19-22.

${ }^{8}$ Alexander WD, McLarty DG, Horton P, Pharmakiotis AD. Sequential assessment during drug treatment of thyrotoxicosis. Clin Endocrinol (Oxf) $1973 ; 2: 43-50$

${ }^{9}$ Greer MA, Kammer H, Bouma DJ. Short-term antithyroid drug therapy for the thyrotoxicosis of Graves's disease. N Englf Med 1977;297:173-6.

${ }^{10}$ Slingerland DW, Burrows BA. Long-term antithyroid treatment in hyperthyroidism. FAMA 1979;242:2408-10.

1 Wise PH, Marion M, Pain RW. Single-dose, "block-replace" drug therapy in hyperthyroidism. Br Med $\mathcal{F} 1973$;iv:143-5.

${ }^{12}$ Wilkin TJ, Beck JS, Crooks J, Isles TE, Gunn A. Time and tides in Graves' disease: their implications in predicting outcome of treatment. Br Med F 1979;i:88-9.

${ }^{13}$ Alexander WD, Harden RMcG, Koutras DA, Wayne E. Influence of iodine intake after treatment with antithyroid drugs. Lancet 1965;ii 866-8.

${ }^{14}$ Wartofsky L. Low remission after therapy for Graves disease. Possible relation of dietary iodine with antithyroid therapy results. $\mathcal{F} A M A 1973$; 226: $1083-8$.

${ }^{15}$ Pimstone B, Joffe B, Pimstone N, Bonnici P, Jackson WPU. Clinical response to long-term propranolol therapy in hyperthyroidism. $S$ Afr Med f 1969;43:1203-5.

${ }^{16}$ McLarty DG, Brownlie BEW, Alexander WD, Papapetrou PD, Horton P. Remission of thyrotoxicosis during treatment with propranolol. $\mathrm{Br} \mathrm{Medf}$ 1973 ;ii :332-4.

17 Lowe DC, Hadden DR, Montgomery DAD, Weaver JA. Propranolol as the sole therapy for thyrotoxicosis; long-term follow up. In: Robbins J, Braverman LE, eds. Thyroid research. Amsterdam: Excerpta Medica, $1976: 429-33$.

${ }^{18}$ Yamamoto M, Totsuka I, Kojima N, et al. Outcome of patients with Graves' disease after long-term medical treatment guided by triiodothyronine (T3) suppression test. Clin Endocrinol (Oxf) 1983;19:467-76.

${ }^{19}$ Bouma DJ, Kammer H, Greer MA. Follow-up comparison of short-term versus 1-year antithyroid drug therapy for the thyrotoxicosis of Graves' disease. F Clin Endocrinol Metab 1982;55:1138-42.

2" Sugrue D, McEvoy M, Feely J, Drury MI. Hyperthyroidism in the land of Graves; results of treatment by surgery, radio-iodine and carbimazole in 837 cases. $Q \mathcal{F}$ Med 1980;49:51-61.

${ }^{21}$ Romaldini JH, Bromberg N, Werner RS, et al. Comparison of effects of high and low dosage regimens of antithyroid drugs in the management of Graves' hyperthyroidism. I Clin Endocrinol Metab 1983;57:563-70.

22.2 Goolden AWG, Williams ED, Thalassinos NC. Studies of thyroid function using $99 \mathrm{Tcm}$ in thyrotoxic patients during treatment with antithyroid drugs. Clin Endocrinol $(O x f)$ 1973;2:65-73.

${ }^{23}$ Wise PH, Marion M, Pain R. Mode of action of carbimazole in Graves' disease. Clin Endocrinol (Oxf) 1979;10:655-64.

${ }^{24}$ Michie W, Beck JS, Mahaffy RG, Honein EF, Fowler GB. Quantitative, radiological and histological studies of the thymus in thyroid disease. Lancet $1967 ; \mathrm{i}: 691-5$.

${ }^{25}$ Beck JS, Young RJ, Simpson JG, et al. Lymphoid tissue in the thyroid gland and thymus of patients with primary thyrotoxicosis. $B r \mathcal{F}$ Surg $1973 ; 60: 769-71$.

${ }^{26}$ Pinchera A, Liberti P, Martino E, et al. Effects of antithyroid therapy on the long-acting thyroid stimulator and the antithyroglobulin antibodies. f Clin Endocrinol Metab 1969;29:231-8.

${ }^{27}$ Fenzi G, Hashizume K, Roudebush CP, DeGroot LJ. Changes in thyroid-stimulating immunoglobulins during antithyroid therapy. $\mathcal{F}$ Clin Endocrinol Metab 1979;58:572-6.

${ }^{28}$ Teng CS, Yeung RTT. Changes in thyroid-stimulating antibody activity in Graves' disease treated with antithyroid drug and its relationship to relapse: a prospective study. $\mathcal{I}$ Clin Endocrinol Metab 1980;50:144-7.

29 McGregor AM, Petersen MM, McLachlan SM, Rooke P, Smith RB, Hall R. Carbimazole and the autoimmune response in Graves' disease. $N$ Engl f Med 1980;303:302-7.

${ }^{30}$ Bech K, Madsen SN. Influence of treatment with radioiodine and propylthiouracil on thyroid stimulating immunoglobulins in Graves' disease. Clin Endocrinol 1980;13:417-24.

${ }^{31}$ Rennie DP, McGregor AM, Keast D, et al. The influence of methimazole on thyroglobulin-induced autoimmune thyroiditis in the rat. Endocrinology $1983 ; 112: 326-30$

${ }^{32}$ Wall JR, Manwar GL, Greenwood DM, Walters BA. The in vitro suppression of lectin induced $3 \mathrm{H}$-thymidine incorporation into DNA of peripheral blood lymphocytes after the addition of propylthiouracil. f Clin Endocrinol Metab 1976;43:1406-9. 
${ }^{33}$ Okita N, How J, Topliss D, Lewis M, Row VV, Volpé R. Suppressor T lymphocyte dysfunction in Graves' disease: role of the $\mathrm{H}-2$ histamine receptor-bearing suppressor $\mathrm{T}$ lymphocytes. $\mathcal{f}$ Clin Endocrinol Metab $1981 ; 53: 1002-7$.

34 Weiss I, Davies TF. Inhibition of immunoglobulin-secreting cells by antithyroid drugs. $\mathcal{F}$ Clin Endocrinol Metab 1981 ;53:1223-8.

35 Jansson R, Dahlberg PA, Johansson H, Lindström B. Intrathyroidal concentrations of methimazole in patients with Graves' disease. $\mathcal{F}$ Clin Endocrinol Metab 1983;57:129-32.

${ }^{36}$ McGregor AM, Smith BR, Hall R, Collins PN, Botazzo GF, Petersen MM. Specificity of the immunosuppressive action of carbimazole in Graves's disease. Br Med f 1982;284:1750-1.

37 Weetman AP, McGregor AM, Hall R. Methimazole inhibits thyroid autoantibody production by an action on accessory cells. Clin Immunol Immunopathol 1983;28:39-45.

${ }^{38}$ Fantone JC, Ward PA. Role of oxygen-derived free radicals and metabolites in leukocyte dependent inflammatory reactions. Am F Pathol 1982; $107: 397-418$

39 McGregor AM, Smith BR, Hall R, Petersen MM, Miller M, Dewar PJ. Prediction of relapse in hyperthyroid Graves' disease. Lancet 1980;i: 1101-3.

41) Schleusener H, Schernthaner G, Mayr WR, et al. HLA-DR3 and HIA-DR5 associated thyrotoxicosis-two different types of toxic diffuse goiter. $\mathcal{F}$ Clin Endocrinol Metab 1983;56:781-5.

\section{Doctoral students and the supervisor's role}

What higher degrees are appropriate to medicine is a matter of controversy. Some would favour a universal doctorate of medicine; others a doctorate of philosophy; yet others opt for specialty such as a mastership of surgery. None can fail, however, to profit from a delightful document from the Science and Engineering Research Council which sets out an approach to good supervisory practice for any or all. ${ }^{1}$ The familiar things that are talked about in common rooms but rarely rationalised in committee are sketched out here.

We all welcome doctoral students, but we do not always accept the responsibility that goes with our acquiescence. As the Science and Engineering Research Council reminds us, we believe that we lack deficiencies in supervising our amanuenses but this is not true. Too often we bask in numbers and relax in commitment. The story goes on by reminding us of the time constraints which govern doctoral research work and the need to set a proper and effective programme. Here there is a dissociation between supervisors' expectations and students' achievements. The former have well defined (in their mind) objectives; the latter get diverted into other channels, particularly in these days of computer "hackery," where the mastery of a technique displaces the imperative to get together a body of work which will impress the scientific establishment. Milestones should be defined ahead and adhered to as the student's development proceeds. Not only is there a need to teach students research techniques but they must also learn to get their professional act together, finding out how to "organise their affairs, something they will certainly have to do if they are going to make a success of any job in later life."

Beginnings, middles, and ends are dealt with in detail. How much the student should originate and how much the supervisor should intrude will always be a matter of controversy, but the Science and Engineering Research Council seems to come down in favour of a well supervised studentship, something which may not always appeal to the independent medical mind.

The last, and ultimately the most important, thing is drafting the thesis. Early on time should be spent in laying out a plan, though the final thesis should be the student's own effort. Again a realistic timetable is essential and is sketched by the Science and Engineering Research Council. One final point which is a fact of life to most of us in charge of higher degree programmes is that if one promotes an individual researcher because he has nearly reached doctoral standard, he may not finally achieve the coveted doctorate. As the report says with impartiality, this may not be bad for science but it does have an impact on salary scales and promotion. In medicine we have yet to learn how to balance a track record against a thesis. They should have different if complementary roles in the development of a career but that obvious conclusion needs to be recognised by both academics and those who sit on appointment committees for substantive positions in the NHS.

H A F DUDLEY

Professor of Surgery,

St Mary's Hospital Medical School,

London W2 $1 \mathrm{NY}$
${ }^{1}$ Christopherson D, Boyd RLF, Fleming I, et al. Research student and supervisor. An approach to good supervisory practice. Swindon: Science and Engineering Research Council, 1983.

\section{Allergy to penicillin}

Allergy to penicillin gives rise to a wide variety of clinical syndromes. ${ }^{1}$ Immediate reactions include anaphylaxis, angiooedema, urticaria, and some maculopapular rashes. Late reactions include those with a well defined immunological basis such as serum sickness like reactions, haemolytic anaemia, and acute interstitial nephritis and others which are less clearly immunological, such as some cases of neutropenia and the maculopapular rashes produced by ar.picillin. Immediate reactions are mediated by IgE antibodies, whereas IgG antibodies are responsible for at least some of the late reactionsfor example, serum sickness and haemolytic anaemia. ${ }^{1}$

Accurate figures for the incidence of allergic reactions to penicillin are not available. The overall incidence has been estimated to be between $1 \%$ and $10 \%{ }^{12}$ in different studies, and anaphylactic reactions are thought to occur in about one to five per 10000 patient courses of treatment. ${ }^{3}$ Fatal anaphylaxis is very rare, but anaphylaxis due to penicillin has been said to cause 400-800 deaths a year in the United States. ${ }^{1}$ Only 22 deaths attributed to acute reactions to penicillin were reported to the Committee on the Safety of Medicines between 1964 and 1983 (personal communication).

Allergic reactions in general are more common with the semisynthetic penicillins ${ }^{3}$ but anaphylaxis is usually due to benzylpenicillin. Anaphylaxis usually occurs after intravenous administration but has been reported after oral administration. ${ }^{4}$

The chemical basis of penicillin allergy is complex and incompletely understood. Penicillins are low molecular weight substances which are not themselves antigenic but give rise to a number of different antigenic determinants either by metabolism in vivo or by breakdown in vitro before administration. ${ }^{15}$ The major antigenic determinant is the penicilloyl group derived from the $\beta$-lactam ring of the penicillin nucleus, and most allergic reactions to penicillin are due to antibodies specific for this group. ${ }^{1}$ Other penicillin breakdown products such as penicillamine and penicilloic acid may also act as haptens and are known as the "minor deter- 